\title{
Sistem Pendukung Keputusan Penentuan Lokasi dan Pemetaan Secara Simultan dengan OLAP
}

\author{
Harindra Wisnu Pradhana ${ }^{\mathrm{a}^{*}}$, Achmad Widodo ${ }^{\mathrm{b}}$

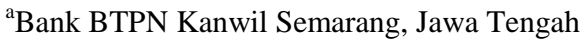 \\ burusan Teknik Mesin, Fakultas Teknik, Universitas Diponegoro
}

Naskah Diterima : 1 Juni 2013; Diterima Publikasi : 20 Juli 2013

\begin{abstract}
This research proposes simultaneous localization and mapping (SLAM) system processed separately from the robot using data warehouse. Information in the data warehouse processed separately to allow complex computation held without lowering robotic system performance. The system helps making decision by analyzing information in the data warehouse. Decision support information visualized in vector graphics to helps robotic information interpretation. This system use online analytical processing (OLAP) on processing and analyzing information in the data warehouse. Visualization process use Scalable Vector Graphic (SVG) to display map from robotic data processing. Web server manages all of the processing and analysis of OLAP information and displays it through browser to the user. This research produces interactive and informative decision support system. The web server quickly process information and displays it to the browser. System processing and analysis generates relevant information with low error. For further research, conventional SLAM methods can be added to the server to operate the information in the data warehouse.
\end{abstract}

Keywords : DSS; SLAM; Data Warehouse; OLAP; SVG

\begin{abstract}
Abstrak
Penelitian ini mengulas simultaneous localization and mapping (SLAM) terpisah dari sistem robotik dengan memanfaatkan data warehouse. Pengolahan terpisah memungkinkan pengolahan kompleks dilakukan tanpa mengganggu kinerja sistem robotik. Sistem ini membantu menghasilkan dukungan keputusan dengan menganalisa informasi pada data warehouse. Informasi dukungan keputusan berupa visualisasi dalam grafik vektor untuk membantu interpretasi informasi robotik. Sistem ini menggunakan online analytical processing (OLAP) pada proses pengolahan dan analisa informasi pada data warehouse. Proses visualisasi menggunakan scalable vector graphics (SVG) untuk menampilkan peta hasil pengolahan data robotik. Web server mengatur seluruh proses pengolahan dan analisa informasi OLAP dan menampilkannya melalui peramban pada pengguna. Penelitian ini menghasilkan sebuah sistem pendukung keputusan yang interaktif dan informatif. Web server dengan cepatnya mengolah informasi dan menampilkannya dalam browser. Pengolahan dan analisa dengan sistem ini menghasilkan informasi yang relevan dengan galat relatif kecil. Penelitian lebih lanjut dapat dilakukan dengan menambahkan metode-metode SLAM konvensional dalam mengolah informasi pada data warehouse.
\end{abstract}

Kata Kunci : Sistem Pendukung Keputusan, SLAM, Data Warehouse, OLAP, SVG.

\section{Pendahuluan}

Permasalahan Simultaneous Localization and Mapping (SLAM) dikemukakan pertama kali dalam IEEE Robotics and Automation Conference pada 1986 di San Francisco. Permasalahan SLAM yang diangkat adalah mungkin tidaknya sebuah robot bergerak secara otomatis dan secara bertahap menyusun sebuah peta sekaligus secara konsisten mendeteksi posisinya pada peta tersebut (DurrantWhyte dan Bailey, 2006).

Dua permasalahan utama pada SLAM adalah lokalisasi robot secara relatif terhadap peta dan pemetaan berkesinambungan yang secara simultan melakukan pengkinian peta yang ada. Berbagai

*) Penulis korespondensi: wisnu@msi.undip.ac.id algoritma terkait SLAM telah dikembangkan untuk menyelesaikan dua permasalahan tersebut dan secara teoritis permasalahan tersebut telah terselesaikan (Durrant-Whyte dan Bailey, 2006). Bagaimanapun juga, masih banyak peluang pengembangan sistem tersebut dengan pengayaan peta sebagai bagian dari algoritma SLAM.

Informasi pergerakan robotik dapat direpresentasikan dalam bentuk vektor untuk memudahkan proses penyimpanan dalam basis data (Pradhana et al., 2013). Vektor dapat dengan mudah dioperasikan dan direkapitulasi untuk estimasi posisi obyek dan robot.

Sebuah sistem SLAM terintegrasi menghasilkan data gerakan dan deteksi berskala besar. Pemecahan 
peta observasi membantu menyederhanakan pengolahan data dan mengurangi kerumitan sistem (Chong dan Kleeman, 1999). Proses pengolahan data SLAM disimpan dalam beberapa peta lokal untuk kemudian dikonsolidasikan menjadi satu peta global.

Algoritma-algoritma SLAM pada umumnya ditanamkan pada microcontroller berukuran kecil yang berfungsi sebagai otak dari sebuah robot. Komputasi yang lebih rumit dapat dilakukan menggunakan sebuah komputer pada sistem terpisah (Pratama, 2013). Perkembangan teknologi komunikasi yang semakin pesat mendukung berbagai proses dilakukan dari jarak jauh. Sebuah informasi di satu tempat memungkinkan untuk diproses di tempat lain seketika data tersebut diterima.

Data warehouse merupakan salah satu sistem yang mampu mengolah sekumpulan besar data dengan efektif dan efisien untuk menghasilkan informasi yang bermanfaat (Hammergren dan Simon, 2009). Informasi-informasi hasil dari pengolahan data warehouse dapat dianalisa untuk kemudian dijadikan dasar penentuan keputusan. Untuk menghasilkan informasi-informasi yang dieprlukan, sebuah data warehouse perlu dilengkapi dengan Online Analytical Processing (OLAP) yang berfungsi menyusun data ke dalam matriks berdimensi tertentu yang kemudian dapat dimanfaatkan dalam menyelesaikan permasalahan SLAM

Penelitian ini memanfaatkan OLAP dalam pengelolaan data deteksi lingkungan dari sebuah robot sederhana. Data hasil deteksi tersebut dikemas dalam beberapa dimensi untuk dianalisa. Hasil analisa data tersebut menjadi informasi kemana robot bergerak dan posisi obyek-boyek yang ditemui kemudian serta melakukan pengkinian terhadap peta yang ada.

Meninjau berbagai penelitian seputar SLAM sebelumnya, telah dihasilkan beragam algoritma yang berhasil menyelesaikan berbagai permasalahan SLAM dengan karakteristik yang beragam. Setiap solusi yang ditawarkan suatu algoritma memiliki kelebihan dan kekurangan masing-masing. Penelitian-penelitian tersebut juga menyimpan dokumentasi berbagai perangkat yang digunakan pada robot baik sistem sensorik dan motorik

Tujuan dari penelitian ini adalah menerapkan sistem OLAP untuk mengolah data SLAM yang mampu menampilkan peta dengan pengkinian otomatis, mengetahui posisi terkini dari agen secara relatif terhadap peta, serta menginformasikan areaarea potensial yang belum dipetakan untuk membantu agen menentukan keputusan kemana langkah eksplorasi selanjutnya.

\section{Kerangka Teori}

\subsection{SLAM}

Salah satu hal yang mendasar pada SLAM adalah dengan beredarnya robot pada area yang dieksplorasi, ditemui besaran korelasi antara obyek yang satu dengan yang lain bergeser sedikit demi sedikit ke sebuah nilai yang semakin akurat. Korelasi antar obyek yang nilainya berkembang seiring pergerakan robot ini dapat dianalogikan sebagai pegas dengan nilai dinamis yang dengan kelenturan tertentu (Durrant-Whyte dan Bailey 2006). Untuk merepresentasikan kondisi ini dibuat peta pegas yang menggambarkan posisi tiap-tiap obyek pada peta serta korelasi antar obyek yang satu dengan yang lain. Bentuk representasi relasi antar obyek pada peta pegas ditampilkan pada gambar 1 .

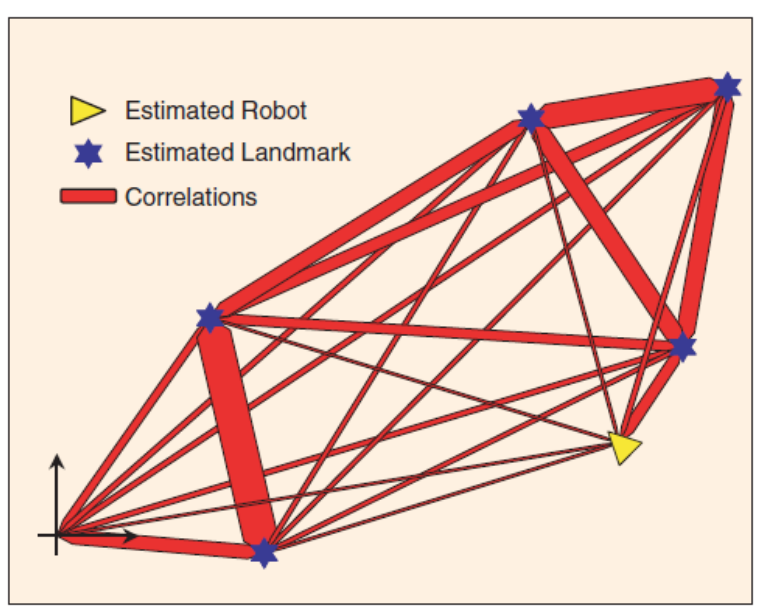

Gambar 1. Analogi SLAM dengan peta pegas (DurrantWhyte dan bailey, 2006)

Untuk efisiensi proses sebuah peta dapat diuraikan menjadi beberapa peta yang lebih kecil (Chong dan Kleeman, 1999), pembagian ini mengelompokkan peta menjadi dua diantaranya adalah :

- Peta Global, adalah peta secara umum yang telah terdeteksi atau diketahui sebelumnya. Berisi seluruh obyek yang telah diketahui posisinya.

- Peta Lokal, adalah peta yang disimpan oleh robot ketika melakukan deteksi, bisa berisi obyek-obyek baru maupun lama yang sudah ada di peta global. Obyek lama ini kemudian dibandingkan dengan peta global sehingga dapat mengkonsolidasikan peta lokal untuk memperkaya peta global.

Bentuk tampilan peta lokal dan peta global serta hasil konsolidasinya ditampilkan pada gambar 2 . 


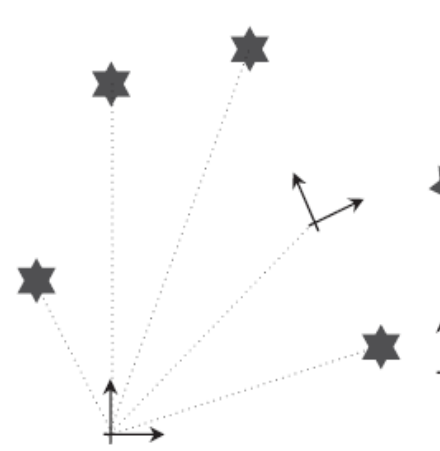

(a)

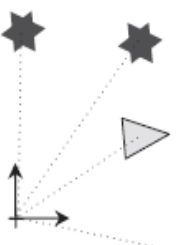

(b)

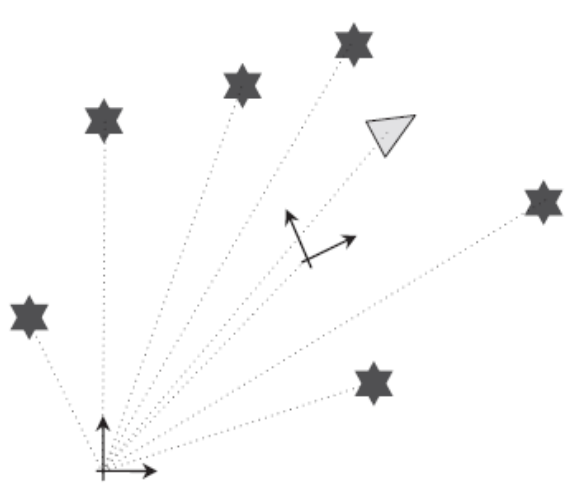

(c)

Gambar 2. Contoh registrasi peta lokal (b) ke dalam peta global (a) sehingga menghasilkan peta global terkini (c) (Bailey dan Durrant-Whyte, 2006)

\subsection{Data Warehouse dan OLAP}

OLAP dalam fungsinya menganalisa data warehouse memiliki kemampuan mengeksplorasi data multi dimensi dan menampilkannya secara lengkap dan terstruktur (Bimonte dan Tchounikine, 2007). Data disusun kedalam kubus yang merepresentasikan komponen-komponen informasi yang hendak dianalisa. Informasi pada OLAP disusun dari data-data yang ada pada data warehouse dengan berbagai metode query. Secara umum data warehouse disusun dalam tiga lapis diantaranya adalah sebagai berikut :

- Warehouse tier, pada lapisan ini seluruh data dikumpulkan dan di proses dengan berbagai operasi untuk menghasilkan informasi yang seragam.

- OLAP tier, pada lapisan ini komponenkomponen informasi disiapkan untuk menyusun kubus informasi yang siap dianalisa.

- Client tier, lapisan ketiga merupakan sisi dari sistem yang berhubungan langsung dengan pengguna. Pada lapisan ini informasi divisualisasikan agar mudah dibaca dan dipahami pengguna.

Ilustrasi arsitektur data warehouse dan OLAP ditampilkan pada gambar 3.

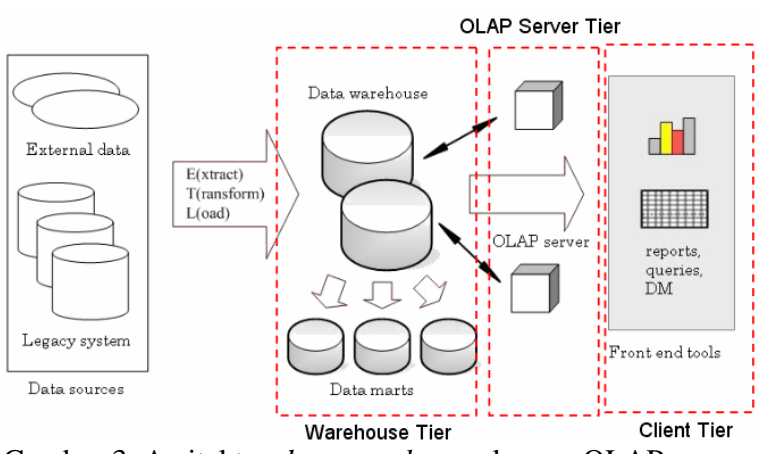

Gambar 3. Arsitektur data warehouse dengan OLAP

(Bimonte dan Tchounikine, 2007)

Untuk kebutuhan pengambilan keputusan masih diperlukan lagi alat bantu yang menjembatani antara pengguna dengan data warehouse. Salah satu alat bantu dalam pengambilan keputusan adalah OLAP. OLAP pertama kali diusulkan oleh E.F Codd yang merepresentasikan informasi ke dalam larik multidimensi (Hammergren dan Simon, 2009).

Operasi OLAP difungsikan untuk memandang informasi dari berbagai sudut pandang berbeda (Hammergren dan Simon, 2009). Beberapa operasi yang didukung oleh OLAP multi dimensi diantaranya sebagai berikut.

- Konsolidasi dengan mengelompokkan beberapa kategori sesuai hirarkinya untuk memperoleh informasi yang lebih global.

- Perincian merupakan kebalikan dari konsolidasi, operasi ini memperinci satu kategori pada dimensi menjadi anggota-anggota yang lebih kecil lingkupnya.

- Pencacahan merupakan operasi membandingkan fakta-fakta yang ada dalam satu lingkup dimensi saja. Sering kali diperlukan untuk mencari hubungan antar dimensi yang dianalisa.

Visualisasi sistem SLAM dapat memanfaatkan Scalable Vector Graphic (SVG) untuk menampilkan peta berbasis web (Pradhana, 2013). Data yang ada perlu dikomposisi untuk menyesuaikan komposisi informasi yang digunakan dalam pemetaan menggunakan SVG.

\section{Metodologi Penelitian}

\subsection{Perancangan Blok Sistem}

Secara garis besar sistem yang dibuat melibatkan tiga elemen utama yaitu agen, server dan client. Agen pada penelitian ini merupakan sebuah robot sederhana dengan berbagai komponen diantaranya adalah microcontroller, servo, sonar, motor stepper dan modul komunikasi bluetooth.

Server pada penelitian ini memiliki beberapa komponen diantaranya modul komunikasi bluetooth, data warehouse, OLAP dan web server. Client pada penelitian ini berupa peramban yang digunakan untuk mengakses sistem. Sistem ini dapat diakses menggunakan berbagai macam peramban, namun 
penulis menyarankan menggunakan Mozilla Firefox atau Google Chrome. Rancangan blok sistem beserta alur proses secara keseluruhan ditampilkan pada gambar 4.

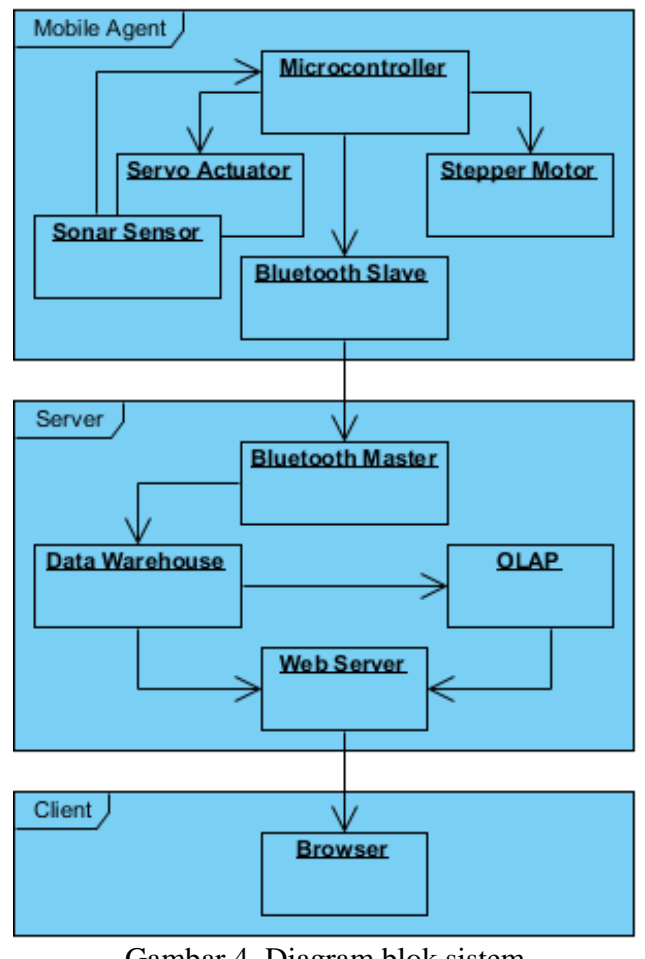

Gambar 4. Diagram blok sistem

\subsection{Perancangan Data Warehouse dan OLAP}

Untuk memudahkan tahapan ini, data dan informasi dikelompokkan dalam beberapa bagian pusat data dengan karakteristik dan fungsional masing-masing. Beberapa kelompok pusat data tersebut antara lain sebagai berikut :

- Input buffer SLAM, berupa basis data sementara dimana seluruh data stream dari agen disimpan sebelum dimuat kedalam basis data.

- Data warehouse SLAM, merupakan area dimana seluruh data disimpan dalam format yang seragam untuk meningkatkan keterbacaan data di dalamnya.

- OLAP SLAM, merupakan area yang tempat seluruh informasi penting dihimpun.

- Output buffer SLAM, berupa basis data sementara yang mengalokasikan informasiinformasi spesifik yang dibutuhkan sistem untuk menampilkan peta global.

Sebelum melakukan rancang bangun lebih lanjut, dilakukan analisa dan perancangan sistem. Sistem informasi dirancang dilakukan menggunakan konsep perancangan berorientasi obyek dengan merepresentasikan sistem informasi kedalam diagram-diagram UML. Gambar 5 menampilkan activity diagram sistem secara keseluruhan.

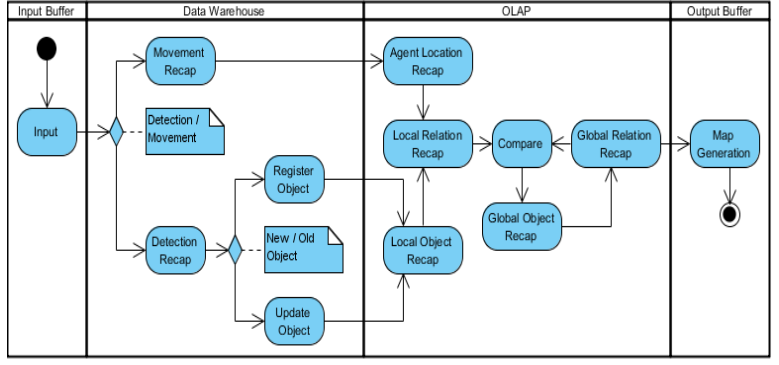

Gambar 5. Activity diagram OLAP SLAM

Sebagai solusi visualisasi SLAM, disusun sebuah skema OLAP. Skema OLAP yang dibuat menampung informasi-informasi yang diperlukan untuk proses visualisasi pada tahapan selanjutnya. Informasi yang dimuat pada skema ini diantaranya adalah sebagai berikut.

- Posisi agen dan obyek relatif terhadap titik acuan

- Relasi posisi antara agen dan obyek serta antar obyek satu dengan yang lain

Gambar 6 menampilkan skema OLAP yang digunakan dalam penelitian ini. Seperti tampak pada gambar, pada sumbu diagonal dicantumkan faktafakta posisi robot dan obyek-obyek yang ada pada sistem sementara di kolom dan baris lain ditampilkan relasi antara dua obyek atau antara robot dan salah satu obyek. Dimensi ketiga dari skema OLAP yang diusulkan adalah dimensi waktu atau posisi step iterasi selama proses penelitian. Fakta-fakta yang ditampilkan pada OLAP disimpan dalam bentuk sistem koordinat polar berupa vektor-vektor.

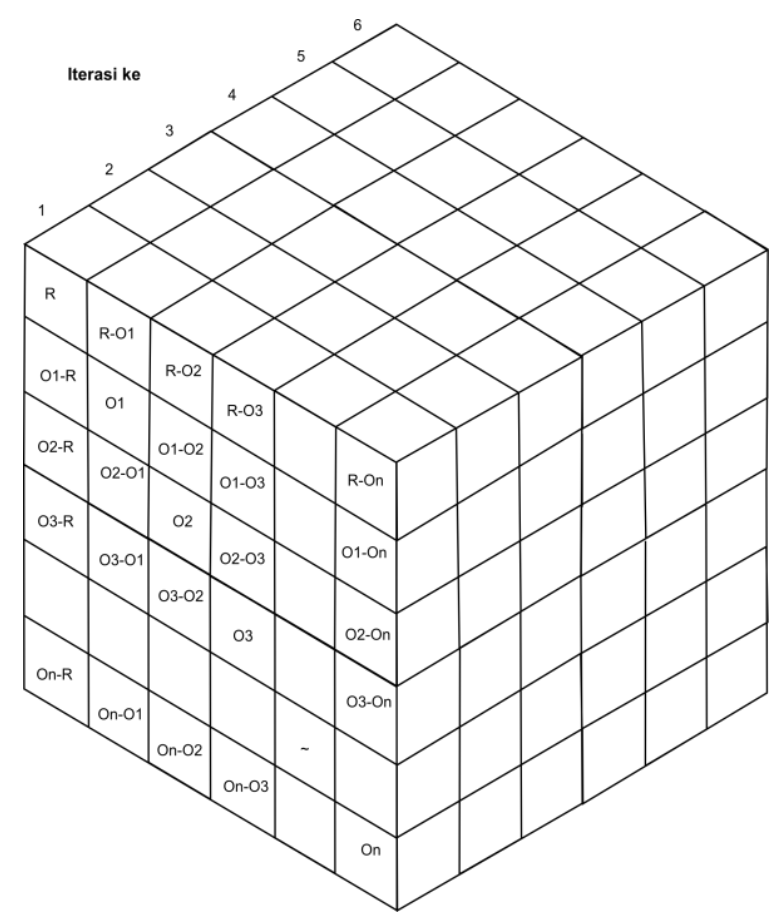

Gambar 6. Skema OLAP SLAM 


\section{Hasil Penelitian}

Sebelum melakukan proses penelitian, dipersiapkan data simulasi yang digunakan untuk pengujian. Data simulasi dipersiapkan dengan merancang posisi-posisi obyek secara acak pada area observasi dan melakukan pengukuran estimasi gerakan dan deteksi robot berdasarkan posisi obyek serta diberikan selisih sebagai estimasi galat yang mungkin terjadi pada ujicoba sebenarnya menggunakan agen. Tabel 1 menampilkan salah satu contoh data simulasi yang digunakan pada penelitian ini. Data simulasi dihitung dengan menggunakan beberapa ketentuan sesuai karakteristik motor dan sensor pada robotik. Seluruh data deteksi dan pergerakan kemudian disusun sebagai data stream yang nantinya diolah oleh sistem.

Tabel 1, Data Simulasi 1

\begin{tabular}{ccccccc}
\hline Step & 1 & 2 & 3 & 4 & 5 & 6 \\
\hline Deteksi & - & - & 68,5287 & 32,240 & 30,131 & 23,17 \\
$(\theta, \ell)$ & & & 33,5013 & 45,354 & 45,258 & 39,156 \\
& & & 18,5181 & $-33,262$ & $-56,184$ & $-56,236$ \\
& & & & $-14,418$ & $-29,312$ & $-21,249$ \\
& & & & & $-1,361$ & \\
\hline \multirow{2}{*}{ Gerakan } & F,3985 & F,3985 & L,151 & L,186 & L,302 & L,20 \\
& & & F,3985 & F,398 & F,398 & F,398 \\
\hline
\end{tabular}

Seluruh data diproses untuk menyusun peta simulasi. Peta simulasi menampilkan gerakan robot beserta proses deteksi obyek di setiap langkah simulasi. Gambar 7 menampilkan peta simulasi hasil pengolahan data pada tabel 1 .

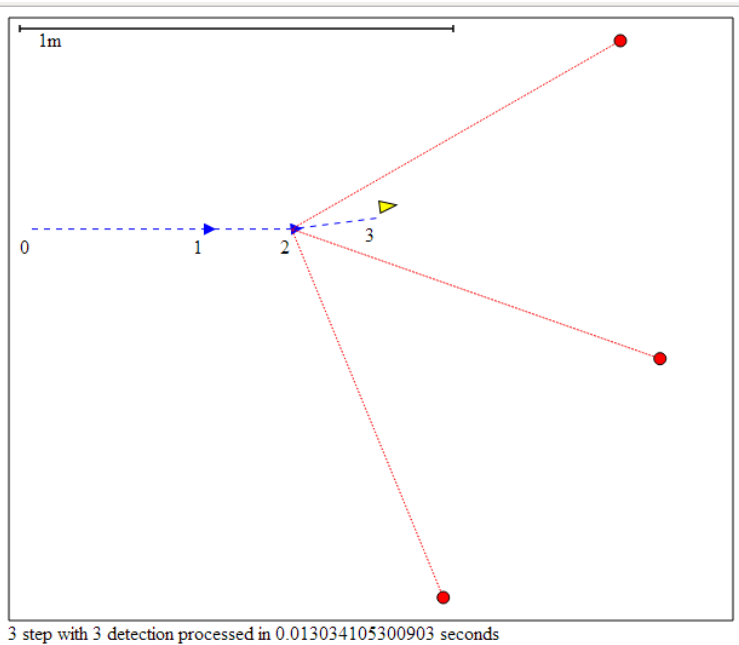

(a)

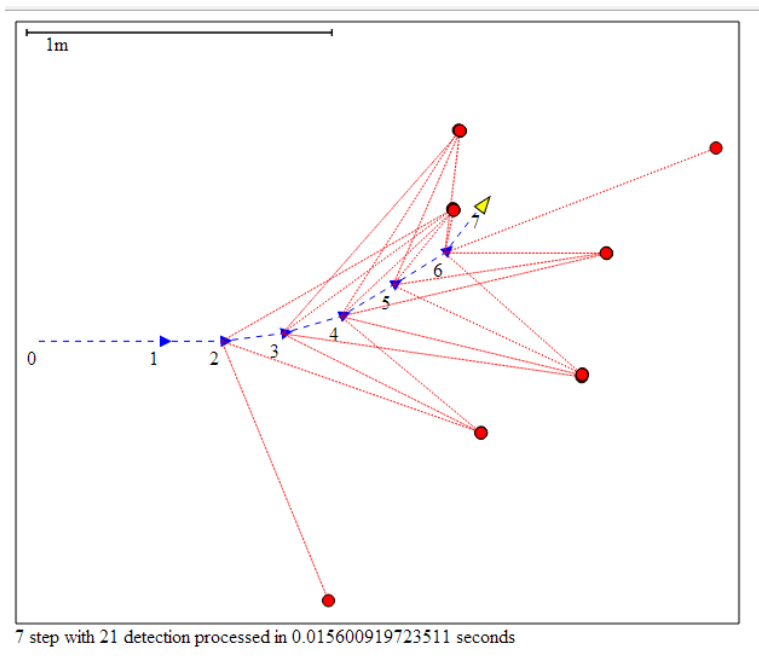

(b)

Gambar 7. Peta simulasi

Langkah selanjutnya pada penelitian ini adalah menyusun peta lokal. Peta lokal menggunakan analogi peta pegas berisi informasi posisi obyekobyek beserta relasi antara obyek satu dengan yang lain. Sebelum melakukan penyusunan peta lokal, perlu dilakukan proses rekapitulasi posisi obyek pada peta. Proses rekapitulasi posisi obyek merupakan interpretasi beberapa hasil deteksi pada step berbeda yang memiliki posisi yang relatif sama atau dekat terhadap titik acuan sebagai satu obyek yang sama. Rekapitulasi posisi obyek menggunakan besaran toleransi sehingga sehingga bila dua titik deteksi masih di dalam radius toleransi tersebut akan dianggap sebagai satu obyek yang sama. Estimasi posisi obyek dilakukan dengan menghitung rata-rata dari seluruh deteksi dalam radius tersebut.

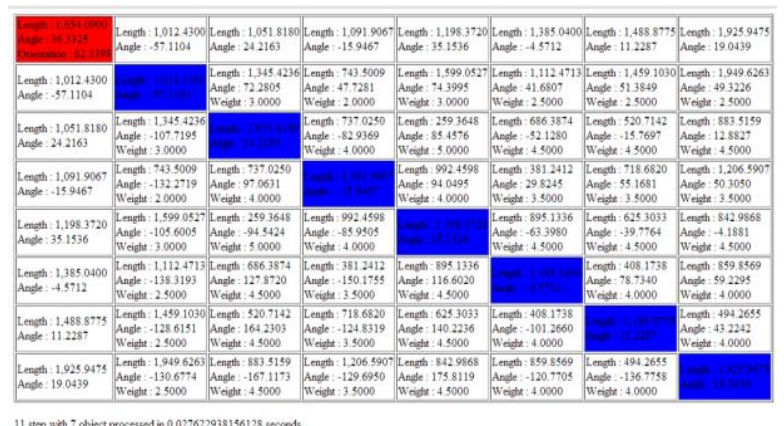

Gambar 8. Skema OLAP data simulasi 1

Gambar 8 menampilkan komposisi informasi pada OLAP hasil pengolahan data simulasi 1 . Sebagai visualisasi sistem menggambarkan peta lokal agar mudah dipahami oleh pengguna. Gambar 9 menampilkan peta lokal hasil pengolahan data simulasi 1. 


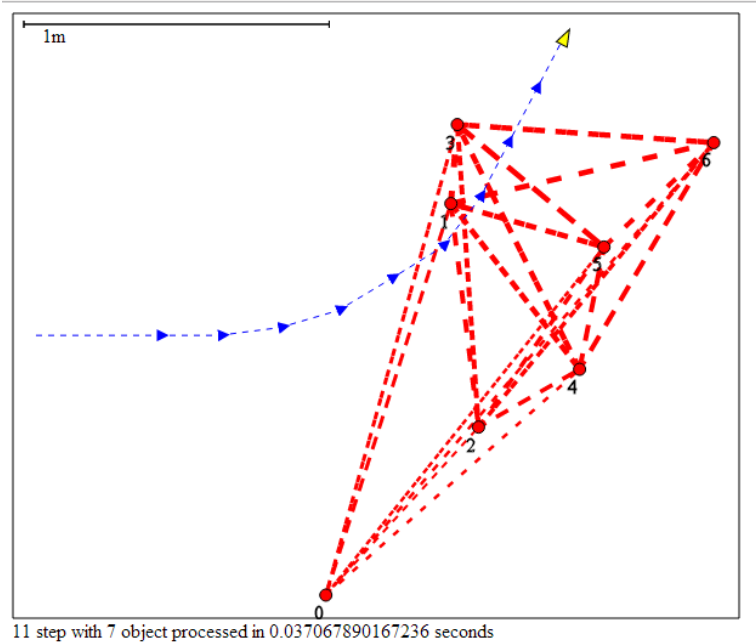

Gambar 9. Peta lokal data simulasi 1

Sistem memproses seluruh data simulasi yang telah dipersiapkan sebelumnya. Alur proses pada data warehouse dan OLAP merekapitulasi data simulasi menjadi beberapa peta-peta terpisah. Seluruh peta simulasi kemudian ditampilkan dalam bentuk peta lokal yang nantinya dikonsolidasikan pada peta global. Hasil rekapitulasi data ditampilkan pada gambar 10 berikut.

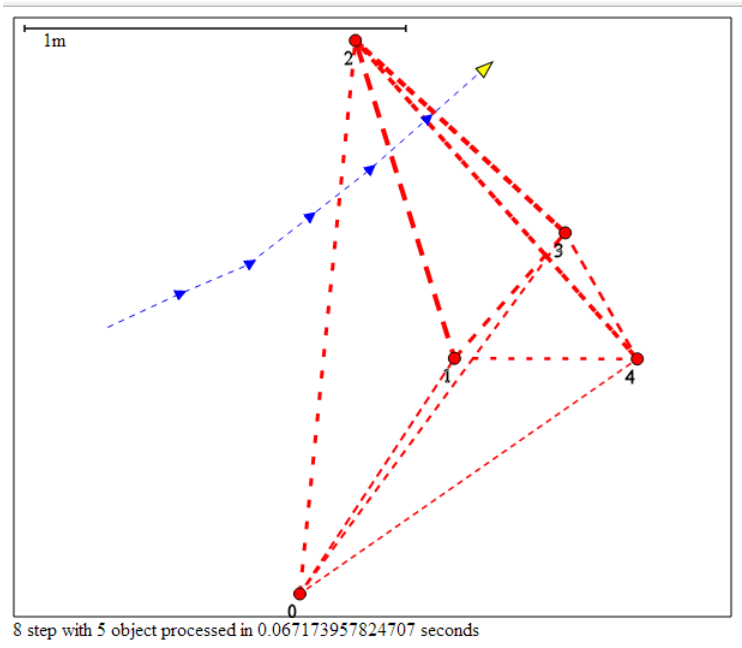

(a)

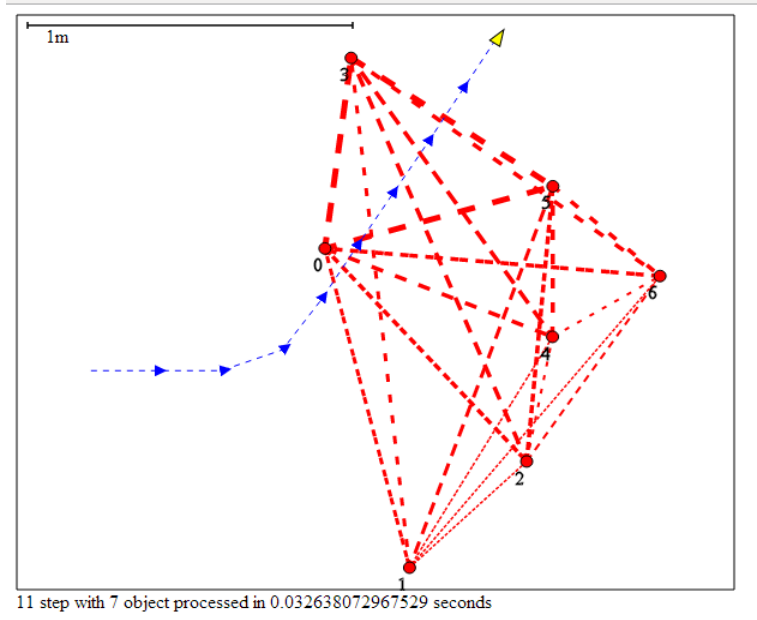

(b)

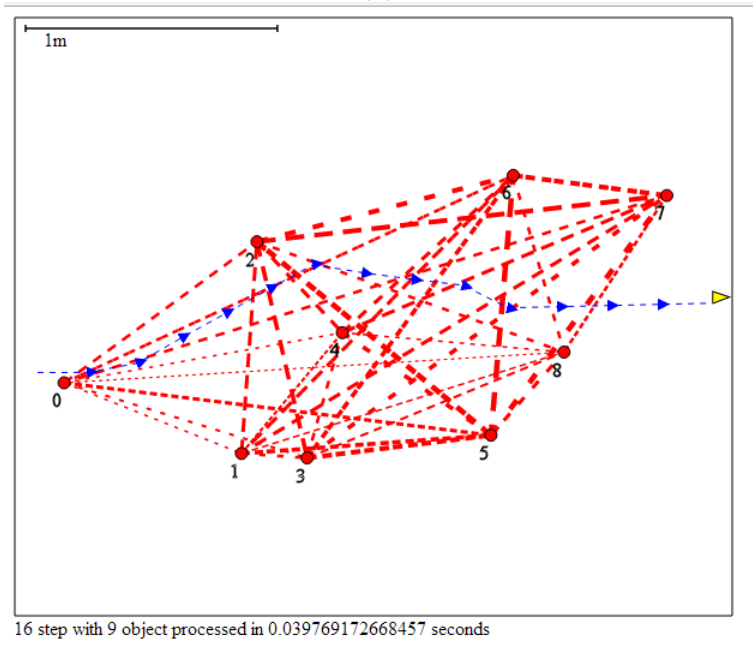

(c)

Gambar 10. Peta lokal (a) data simulasi 2, (b) data simulasi 3, (c) data simulasi 4

Proses awal konsolidasi peta adalah menentukan peta yang hendak dijadikan dasar dari peta global, seluruh informasi pada peta ini kemudian akan dijadikan data awal dari peta global. Setelah memilih peta lokal sebagai acuan, proses konsolidasi berlanjut dengan mendeteksi obyek-obyek pada peta lokal yang relevan dengan obyek yang ada pada peta global sehingga dapat dijadikan acuan relatif antara kedua peta. 


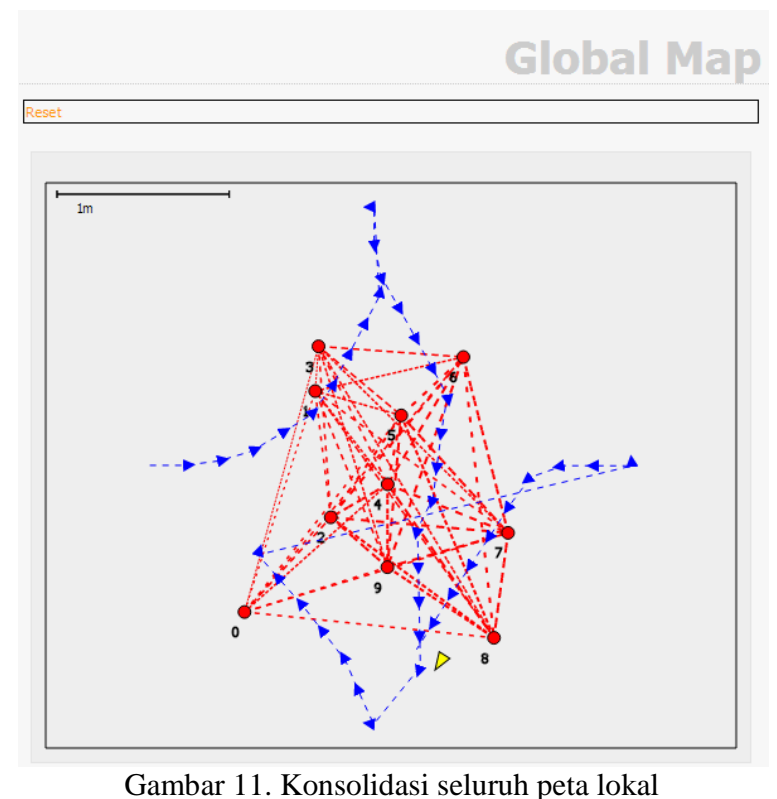

Gambar 11 di atas menampilkan seluruh peta lokal yang telah dikonsolidasikan ke dalam peta global. Sistem merekapitulasi seluruh obyek dengan memperkirakan posisi rata-rata obyek yang berdekatan dan dalam toleransi tertentu sebagai satu obyek yang sama.

\section{Kesimpulan}

SVG mampu menampilkan peta lokal maupun peta global dari sistem SLAM yang dikemas dalam skema OLAP. Rekapitulasi data robotik pada data warehouse dapat menghasilkan posisi terakhir agen secara relatif terhadap peta dengan menggunakan konsep penjumlahan vektor.

Visualisasi peta global dari sistem SLAM dapat membantu menginformasikan area-area potensial yang belum dipetakan. Interpretasi data robotik dalam bentuk vektor memudahkan analogi dan pengolahan data.
Relasi antar obyek pada sistem SLAM dapat dijadikan acuan proses konsolidasi antar peta lokal, semakin banyak obyek yang relevan pada kedua peta yang dikonsolidasikan semakin tinggi pula tingkat keyakinan akan relasi kedua peta tersebut.

\section{Daftar Pustaka}

Bimonte, S. and Tchounikine, A., 2007. Spatial OLAP: Open Issues and a Web Based Prototype, 10th AGILE International Conference on Geographic Information Science, Aalborg, May 8-11,

Chong, K.S. and Kleeman, L., 1999. Feature-based Mapping in Real Large Scale Environment using an Ultrasonic Array, The International Journal of Robotic Research, 18(1): 3-19.

Durrant-Whyte, H. and Bailey, T., 2006. Simultaneous Localisation and Mapping (SLAM) Part I : The Essential Algorithms, IEEE Robotics \& Automation Magazine, 13(2): 99-110.

Hammergren, T.C. and Simon, A.R., 2009. Data Warehousing for Dummies 2nd Edition, John WileyJohn Wiley \& Sons, Hoboken, NJ.

Pradhana, H.W., Suryono and Widodo, A., 2013. Visualization of Simultaneous Localization and Mapping using SVG, Proceeding of The 2nd International Conference on Information System for Business Competitiveness, Semarang, Desember 5.

Pradhana, H.W., Widodo, A. and Suryono., 2013. Web Based Map Generations of Mobile Robot Movement using Scalable Vector Graphic, Proceeding of The 1st Conference on Information Technology, Computer, and Electrical Engineering, Semarang, November 16, 23-27.

Pratama, P.S. and Kim, S.B., 2013. Obstacle Avoidance Algorithm Based on Velocity and Orientation Controls of Differential Drive Automatic Guided Vehicle. Master thesis, Pukyong National University. 
